\title{
2 \\ Responding to HIV/AIDS: Mobilisation through partnerships in a public health crisis
}

\author{
Lisa Fitzgerald and Allyson Mutch, with Lisa Herron ${ }^{1}$
}

\section{Australia's response to HIV/AIDS}

As incoming Minister for Health, I was presented with a ministerial briefing, a fat folder with health issues roughly organised in order of priority. Well down the list, at 34 or 35, there was a reference to a phenomenon entitled GRID—gay-related immune deficiency. I was informed that this was a fatal immune disorder affecting homosexuals in the conditions or 'life styles' of American gays. It was not, I was assured, likely to be of any immediate priority for an Australian minister. Within two years, we had close to 1000 cases of human immunodeficiency virus [HIV] infection in Australia. AIDS, as it was by then called, had moved near the top of the national agenda. (Blewett 1996: 343)

When Neal Blewett, the newly elected Commonwealth Minister for Health, took office in 1983, AIDS was a new, unidentifiable, infectious and lethal disease affecting some of the most stigmatised communities

1 We would like to acknowledge and thank our colleagues Chris Howard, Bernard Gardner and Kate van Dooren. We would particularly like to thank Chris and Bernard for drawing on their extensive knowledge and experience of the HIV field to provide insight and critique. We also acknowledge people living with HIV who so generously share their lived experiences to improve the lives of all people living with HIV. 
in Australia. There were no medical explanations, little understanding of the communities affected and no overseas policy models to guide action. Australia's response to HIV/AIDS required a new approach (Blewett 1997). What followed was groundbreaking policy embedded in three key principles: partnership, community engagement and bipartisan support. This framework has ensured Australia's national policy response to HIV/AIDS has been lauded as one of the best in the world (Gupta et al. 2008; Brown et al. 2014; Holt 2017).

\section{Evaluating policy success}

What were the foundations of Australia's HIV policy success? At the programmatic level, a strong values base of human rights and collaborative partnership between government, affected communities, clinicians and researchers has underpinned national policy (Bowtell 1997; Drielsma 1997; Brown et al. 2014). Social public health, centred on social and collective experiences of HIV, has been fundamental to policy design, with the focus on facilitating and enabling the social and legal environments for affected communities (Aggleton and Kippax 2014). The first Australian National HIV/AIDS Strategy, in 1989, closely adhered to these values as it sought to define policy goals: restrict the spread of HIV/AIDS transmission, care for those infected and educate and support healthcare professionals (Commonwealth of Australia 1989). Subsequent national strategies have maintained this strong values base, but policy goals have evolved.

The outcomes of Australia's national HIV/AIDS policy clearly illustrate its success. Australia's sustained low prevalence of HIV is comparable with other resource-rich countries (Holt 2017). Since 1984, 37,225 people have been diagnosed with HIV, and 27,545 people were living with HIV in 2017 (0.13 per cent of the population) (Kirby Institute 2018). This compares with 0.16 per cent of the population in the United Kingdom and 3.9 per cent $(392.4$ per 100,000) in the United States (Kirwan et al. 2016; CDC 2018). Within Australia, the epidemic has been contained in the groups initially impacted (Bowtell 2005): men who have sex with men (70 per cent of new cases in the past decade); a few cases in people who inject drugs; and no recorded cases between sex workers and clients (Holt 2017). But success should not be measured only epidemiologically. The collaborative nature of policy design and the empowerment of affected 
communities have seen increased awareness of the human rights of marginalised groups, including people living with HIV (PLHIV); lesbian, gay, bisexual, transgender and/or intersex (LGBTI) people; sex workers; and people who inject drugs. Radical changes in community behaviour, including a revolution in safe sex and drug-using practices, have occurred (Brown et al. 2014). Outcomes of the policy process have included policy partnerships, innovative public health programs and healthcare services, linkages between primary care, specialists and community organisation services and research engaging the community, health providers and policymakers (Department of Health 2014).

HIV emerged in Australia at the time that Medicare-the nationally coordinated universal health insurance system-was introduced, in 1984 (Chapter 11, this volume), which was fundamental to providing care for those who developed AIDS and for funding ongoing support and treatment of PLHIV (Bowtell 1997). The Pharmaceutical Benefits Scheme (PBS), Australia's subsidised medication scheme, provided copayments for HIV-related medications including biomedical prevention medication such as pre-exposure prophylaxis (PrEP). Federal and state governments also cofunded community-supported education and prevention. Modelling demonstrates that significant investment in prevention and care has saved billions of dollars through averted infection and expenditure on treatment and care (Applied Economics 2003; Kwon et al. 2012).

At the process level, the design and choice of policy instruments have been contextual, innovative and at times remarkably courageous. At the beginning of the Australian epidemic, well before policy formulation, affected communities harnessed the momentum achieved through their rights-based movements to lead the response (Power 2011). Government drew on this action, resourcing communities to 'own' their epidemic and work with peers (Mindel and Kippax 2013). Under the strong leadership of Blewett, the Hawke Labor Government worked within a model that valued the inclusion of affected communities in policy decision-making processes, community-led education and prevention strategies and resource allocation (Bowtell 1997; Brown et al. 2014). HIV/AIDS policy development was an example of 'grassroots-up' policy design (Bowtell 2005: 5). Well-resourced, empowered affected communities provided rapid feedback loops to mobilise the community and identify solutions 
that fed into policy (Nous Group 2015). This participatory strategy was an essential contributor to policy success (Misztal 1991; Kippax and Race 2003; O’Donnell and Perche 2016).

The policy process effectively and adaptively deployed a mix of policy instruments. Social policy dimensions were prioritised across multiple social, political, behavioural and health service levels, operating within supportive environments and national and state policy development and reform, with reorientation of health services and research investment (Brown et al. 2014). Innovative harm-reduction prevention programs and peer education were developed around the sensitivities of (stigmatised) health-related practices (AFAO 2012). The multipronged mix of policy instruments has been flexible, adapted to evidence and changing epidemics, and has supported the diversity of priority populations and contexts. A pragmatic, evidence-based approach that values different types of evidence, including the knowledge and understandings of affected communities, makes this policy so innovative. National centres in social, epidemiological and medical research have conducted groundbreaking research that has enabled policy design to be shaped by evidence (Bernard et al. 2008; Brown et al. 2014). The collaborative process undertaken in the development of policy_including the establishment of innovative policy instruments—has been an essential element of success (AFAO 2012).

At the political level, policy was established through a broad and deep political coalition and continues through commitment to bipartisanship. A multisectoral approach-across federal and state/territory governments and opposition parties, community groups, clinicians and researchershas been a feature (Bowtell 2005). The mobilisation of goodwill and public support has seen early political players-particularly Blewett and his opposition counterpart, Dr Peter Baume-praised for their action and success. Australia has been a key player driving international HIV policy over the history of the epidemic, including through the 'Melbourne Declaration' in 2014 (Whittaker 2014). Many bestpractice policy approaches developed in Australia have been taken up internationally (AFAO 2012). Leading community organisationsincluding the Australian Federation of AIDS Organisations (AFAO), Scarlett Alliance and the National Association of People with HIV Australia (NAPWHA) — are internationally recognised and work globally. In terms of public legitimacy, enduring national HIV policies have been 
supported by the majority of Australians and the response has been cited as a successful demonstration of leadership and willingness to make decisions (Bowtell 1997).

It is at the temporal level that the success of Australia's national HIV policy has been challenged due to complex and shifting epidemiological, biomedical, social and political contexts. Policy success has waxed and waned through temporal and contextual complexity, yet the underlying value proposition of human rights, partnership and social public health has endured and adapted to changing circumstances. Bipartisan commitment has continued across national strategies and through successive federal and state governments (Brown et al. 2014). However, the degree to which the policy's programmatic, process and political performance has been maintained over time is a more complex story and 'not without periods of disharmony or different levels of participation and/or commitment' (Brown et al. 2014: 38).

This chapter outlines nearly 40 years of policy development in HIV/ AIDS. The story is not a snapshot but a long film with a complicated script, and many characters and scenes. We, as public health academics, are the directors, and consequently the focus of this chapter is on the story of Australia's national HIV policy, not those of the states and territories (each state/territory has its own story to tell—some successful, others with mixed results). We outline the history of national policy processes, teasing out key successes, and highlight how performance and legitimacy have been maintained and challenged. We discuss the strong foundational, programmatic and values base of Australia's policy response, and the tensions/challenges in this story of success, particularly in temporal policy and political processes. These tensions and challenges occur through shifting contexts-most notably: 1) the changing context of HIV (biomedical advancements in treatment and prevention, the movement of HIV as a manageable chronic condition and the increasing diversity of affected communities); and 2) changing governments and neoliberal policy agendas (shifts in and reductions of funding and increasing focus on biomedicalisation). This complex historical narrative comprises three acts: 1982-95, the early response of partnerships and prevention; 1996-2009, 'new hope, disinvestment and political neglect' (Brown et al. 2014: 37); and 2010 to the present, a time of targets and biomedicine (Newman et al. 2010; Brown et al. 2014; Cameron and Goodwin 2014). 


\section{Australia's HIV/AIDS policy in context}

To consider the success of Australia's immediate and enduring approach to HIV, the first part of our 'film' examines the social, historical and political contexts that shaped early policy and provided the foundations for action. In 1981, the first official report of what would become the start of the AIDS epidemic was published by the US Centers for Disease Control and Prevention (CDC 2006). The CDC (2006) identified a rare illness, pneumocystis, that had infected five gay men in Los Angeles; within days, doctors from across the country were registering similar cases. By the end of 1981, 270 cases and 121 deaths from what was then known as gay-related immune deficiency (GRID) had been reported in the United States (CDC 2006). Mainstream and gay media in the United States reported the 'gay pneumonia', often using stigmatising terms including 'gay cancer' and 'gay plague' (Power 2011). In 1982, acquired immune deficiency syndrome (AIDS) became the official name for the mystery disease with no known cause or cure (Robinson and Wilson 2012).

Australia's first case of AIDS, diagnosed in an American tourist, was identified in October 1982 in Sydney. Six months later, the first Australian citizen, who had been living overseas, was diagnosed, in Melbourne, and, on 8 July 1983, the first Australian died from AIDS (Brown et al. 2014). The epidemic grew rapidly from there: between 1983 and 1985, an estimated 4,500 Australians_-predominately gay men living in Sydney and Melbourne-were infected with HIV (Brown et al. 2014). As the disease spread, media reporting followed. In 1982, six months after Australia's gay press began reporting on AIDS, mainstream media picked up the story (Mindel and Kippax 2013). Coverage increased dramatically as time went on, escalating when four Queensland babies died in November 1983 after receiving blood transfusions containing HIV (Plummer and Irwin 2006). As media reports increased, so too did public concern that AIDS would spread to heterosexual communities (Brown et al. 2014). Public outcry, along with the increasing incidence of AIDS and growing numbers of people dying, was a catalyst for activism and support within the gay community.

Brandt (1986: 231) observes that the 'way a society responds to problems of disease reveals its deepest cultural, social and moral values'. HIV was associated with social and sexual practices considered by many at the time to be deviant and immoral (Power 2011). HIV/AIDS predominantly 
affected marginalised groups in Australian society: gay men, sex workers and drug users. The historical context of stigma and discrimination experienced by these populations, along with restrictive laws associated with socially prescribed 'deviant practices', was the key context in which the policy response was situated. Homosexual behaviour between men remained illegal in many Australian states until the mid-1980s, and into the 1990s in Queensland and Tasmania. Punitive legislation related to sex work and people who injected drugs was also a key barrier to HIV prevention (Feachem 1995).

\section{Mobilisation of the gay community}

Mobilisation of the gay community from the outset of the epidemic was as much about the threat of AIDS as it was about the threat to fledgling civil liberties and emerging public acceptance of gay men and lesbian women in Australia (Power 2011). The gay and lesbian rights movement was a feature of Australia's political landscape well before the emergence of AIDS and became vital to policy formation (Power 2011). Homophobia was historically entrenched within Australian society, with legal, religious and medical efforts to punish and control homosexuality (Power 2011). The emergence of new political movements from the 1960s_-for example, for the rights of women, Aboriginal and Torres Strait Islander peoples, people living with disabilities, gay men and lesbian women—advanced new social agendas. Gay and lesbian activism demanded civil rights, legal protection and the decriminalisation of homosexuality. This activism provided increasing visibility through the emergence of gay communities, particularly in Sydney and Melbourne, and new frames of understanding for LGBTI communities (Power 2011).

This history of organised activism meant gay men were in a strong position to respond to the arrival of AIDS in Australia (Drielsma 1997; Bowtell 2005; Power 2011; Mindel and Kippax 2013). The gay liberation movement prompted the formation of geographically dense social and sexual networks, connections to left-wing politics and close relationships between communities. The Australian movement was linked to international gay liberation movements, particularly in the United States (Mindel and Kippax 2013). Communication between gay communities internationally meant Australia received up-to-date information about HIV/AIDS and was able to respond rapidly. Gay men active in the liberation movement were highly educated and articulate, with skills in advocacy and political lobbying; they also quickly became experts in 
scientific and medical information about the virus (Mindel and Kippax 2013). Existing organisational structures and political frameworks, as well as gay and lesbian media, were reoriented immediately to focus on the epidemic (Power 2011). Gay communities in Sydney, Melbourne and Brisbane drew on their resources to organise socially and politically (Altman 1994). Urban gay communities became the battlegrounds in the war on AIDS (Altman 1994). The gay community was passionate about effective prevention and care of those affected. Community volunteerism was a feature of the early response, with people taking on formal caring roles when healthcare providers would not. New partnerships were formed between PLHIV, carers and healthcare providers, based on holistic models of health. This mobilisation occurred across the developed world, where existing gay organisations, communities and networks produced the early prevention, education and care responses-well before action from AIDS organisations or governments (Kippax and Race 2003).

The first community-based organisations established in Australia, in 1984, included the AIDS Action Committees in New South Wales, Victoria, Western Australia and the Australian Capital Territory (ACT) (Mindel and Kippax 2013). Their purpose was to lobby government and educate the community (Plummer and Irwin 2006). The action committees became AIDS councils-established in all states and territories by 1985 . The AIDS councils produced early HIV prevention material, which was recognised as highly successful in raising awareness of HIV and safe sex (Mindel and Kippax 2013). These organisations also continued the fight for structural policy changes, including the decriminalisation of homosexuality.

\section{Activism and PLHIV}

As the epidemic took hold, PLHIV also began to play an active role in advocacy and the politicisation of their rights. PLHIV participated in organisations such as the AIDS Coalition to Unleash Power (ACT UP), which were involved in treatment activism (Whittaker 1992). Internationally, the Denver Principles 1983 and 'The Greater Involvement of People Living with HIV (GIPA) Declaration' of 1994, signed by the Australian Government, were guiding principles for the meaningful participation of PLHIV in all stages of policy and program development and implementation. The NAPWHA was formed in 1989, representing community-based organisations of PLHIV. NAPWHA has 
been a key organisation working with government, providing advocacy, policy, health promotion and presentation on a national level and making sure the voices of HIV-positive people are heard (NAPWHA 2017).

\section{Advocacy within the sex worker community}

Advocacy within the sex worker community also occurred in the early stages of Australia's epidemic. Sex work organisations were established in Australia in the late 1970s, with a focus on advocating for sex workers' health and industry and legal concerns. In response to HIV/AIDS, sex work groups formalised and new groups were established in all states and territories (Bates and Berg 2014). From 1986, sex work organisations received government funding for work related to HIV/AIDS, enabling them to formalise organisational structures, employ staff and develop peer education programs (Bates and Berg 2014). Scarlet Alliance (the Australian Sex Workers Association) was formed in 1989. The enabling environment established for sex workers to provide effective preventive education to peers and clients was immensely successful. Peer education programs improved working conditions, educated clients and promoted safe sex practices. These actions were instrumental in lowering rates of sexually transmitted infections and prevented the spread of HIV within Australia's sex work population (Donovan et al. 2012).

\section{Mobilisation of people who inject drugs}

People who inject drugs were also a key group during the early phase of the epidemic; however, due to the high stigmatisation of drug use, mobilisation of this group occurred slightly later than action within the gay and sex work communities. Community mobilisation developed alongside the adoption of harm minimisation as the official national drug policy in 1985 (Madden and Wodak 2014). Gay organisations provided models to drug-user groups around advocacy and mobilisation to fight HIV/AIDS, enabling them to make a significant contribution to Australia's response to HIV (Madden and Wodak 2014). They advocated for harmreduction drug policies and education, established peer education and needle exchange programs and fought for free and non-judgemental access to sterile injecting equipment and accurate information about HIV. In 1989, the Australian IV League formed, representing the interests of injecting drug users (Hulse 1997). 


\section{Mobilisation of Aboriginal and Torres Strait Islander communities}

From the outset of the epidemic, Aboriginal and Torres Strait Islander peoples mobilised, recognising the potential threat from the epidemic to their people and communities. Aboriginal and Torres Strait Islander peoples' issues were included from the beginning of the response, with partnerships forged between Indigenous peoples, government and affected communities in national and jurisdictional HIV policy development. Focus was placed on workforce development, surveillance and the establishment of Aboriginal and Torres Strait Islander-specific HIV-related organisations and projects (Ward et al. 2014). The Aboriginal Community Controlled Service movement, developed in the 1970s, designed and delivered locally relevant HIV promotion messages, including the successful 'Condoman' and 'Lubelicious' campaigns (Ward et al. 2014).

\section{Political context and leadership}

The political context of the time also had a significant impact on Australia's policy response. As the epidemic emerged, the newly elected Hawke Labor Government took power, in March 1983. The Labor Government was philosophically predisposed to federalism and centralisation of political initiatives and had a strong belief in preventive and community health programs. One of its earliest policy initiatives was the implementation of Medicare (Chapter 11, this volume). Having a national healthcare system funded and driven federally enabled the government to develop a nationally structured and coordinated approach to HIV/AIDS that could be implemented by state and territory governments in accordance with local contexts and needs (Misztal 1993).

Dr Neal Blewett, the Commonwealth Minister for Health (1983-90), is praised as a key actor and architect of Australia's policy response to HIV/AIDS (Ballard 1989). Blewett (1997), a former professor of political science, believed in the socialisation of health, moving away from the monopolisation of health policy by medical professionals and health bureaucrats. He drove the implementation of Medicare, which saw the government and the union movement pitted against a medical establishment opposed to the socialisation of health care (Misztal 1991; Drielsma 1997). 
When Blewett took office, AIDS was a new and incurable communicable disease, which politicians, clinicians and bureaucrats knew little about and were unready to manage. Blewett (1996: 343) recognised that being unprepared had its advantages; there was 'no bureaucratic elite to struggle against' and 'no group of medical specialists with a vested interest in the field', providing a 'rare opportunity for creative policy making'. Blewett focused on what he has called a 'rational approach' to policymaking:

$[\mathrm{W}] \mathrm{e}$ are for the first time in history in a position to address rationally a major new disease, and we must let the logic of the epidemic impose itself on planning decisions. (Blewett 1996: S237)

Debate about the early direction of AIDS policy in Australia occurred within a sociocultural context in which the traditionally dominant medical profession's claim to ownership was challenged, and conflict arose between medical professionals and affected communities over control and self-determination (Drielsma 1997). This conflict reflected two distinct positions: medicine's traditional 'public health medical model', which focused on diagnosis, treatment, isolation and quarantine; and the 'new public health', enshrined in the Ottawa Charter for Health Promotion, which focused on the social determinants of health, equity, social justice, advocacy, intersectoral community-based responses, prevention and health promotion (Drielsma 1997; Madden and Wodak 2014).

AIDS was a 'public health crisis' affecting marginalised communities (Wodak and Lurie 1997: 129). Blewett (1988) recognised the need for a creative and rapid response, but he also acknowledged the need to address public fear about AIDS and provide reassurance that rational government action could stop it. In late 1984, Blewett toured the United States - a trip he described as the most influential experience directing his early views of AIDS (Blewett 1988). The tour highlighted US president Ronald Reagan's slow, partisan and limited national policy approach, as well as the work being done in California, which was characterised by partnerships between medical professionals and affected communities, in both public health campaigns and service delivery (Perrow and Guillen 1990). This prompted Blewett to strive for a national nonpartisan approach and the active engagement of affected communities (Mindel and Kippax 2013). 


\section{Designing, implementing and delivering a national response to HIV}

As the social and political contexts of the 1970s and 1980s shaped Australia's early community response to HIV/AIDS, so, too, policy has adapted and evolved in line with social, epidemiological, political, medical and generational changes over the past four decades. Reflecting these changes, we identify three distinct policy periods: 1982-95, which saw the early response of partnerships and prevention; 1996-2009, a period of 'new hope, disinvestment and political neglect' (Brown et al. 2014: 37); and 2010 to the present, a time of targets and biomedicine (Newman et al. 2010; Brown et al. 2014; Cameron and Godwin 2014). The objectives and policy measures adopted during these eras demonstrate the temporal success of Australia's HIV policy and its ability to reflect the changing nature of the epidemic and evolve with emerging evidence and evaluation of national strategies and interventions. The following acts of our film traverse these three policy periods, considering design, development, implementation and delivery processes, particularly in relation to Australia’s seven national HIV/AIDS strategies.

\section{2-1995: The early response-Partnership and prevention}

The AIDS issue was not a value-neutral political space. To contain the virus, the government needed to negotiate tensions between encouraging safe sex and drug-using practices and the moral discourses that stigmatised affected communities. Acknowledging this, Blewett (1988: S236) saw an urgent need to confront public fear with clear and concise political leadership and strong policy that engaged affected communities in the development of effective strategies to address socially 'taboo practices'. Working in partnership with affected communities, clinicians, researchers, senior health bureaucrats and the states and territories, Blewett actively led the nation's response, establishing the legitimacy needed to support the first National HIV/AIDS Strategy in 1989.

The federal government, largely supported by the states and territories, played multiple roles in the establishment of a multifaceted AIDS policy. Early on, it established its position as consultant and negotiator, bringing together key stakeholders (Moodie et al. 2003; Mindel and Kippax 2013). Through partnerships, the federal government was also positioned as 
an enabler, facilitating and funding innovative and effective education strategies, safe sex campaigns, needle exchange programs and communitybased care programs developed and implemented by affected communities (Plummer and Irwin 2006). Stepping through this discussion of policy design, development and implementation, we reflect on these key roles and consider their contribution to the legitimacy and success of the national strategy in the first policy era.

\section{Consultation and negotiation}

Policy development relies on good-quality information and evidence; however, beyond information and evidence generated by and disseminated through affected communities, traditional sources of health information were notably absent in the early 1980s. Acknowledging this, Blewett (1988) established channels of communication and advisory structures that included representatives of affected communities and medical professionals to inform the nation's health ministers. These advisory structures did not follow the traditional health policymaking processes frequently monopolised by senior bureaucrats and medical professionals, but instead demonstrated the government's commitment to consultation and the engagement of all interested groups (Bowtell 1997, 2005).

The first advisory group began as a working party established by the National Health and Medical Research Council in June 1983 (Ballard 1989). This group was reconstituted in late 1984 as the AIDS Task Force to provide scientific and medical advice (Mindel and Kippax 2013). The National Advisory Committee on AIDS (NACAIDS) followed in November 1984 and provided advice on education and prevention. NACAIDS included state and federal government representatives (early on, Queensland refused to participate as its government did not support the inclusion of representatives from the gay community), representatives of the AIDS councils, the Australian Federation of Haemophilia and other key non-governmental organisations (Hulse 1997). The two advisory groups were designed to ensure information from affected communities, along with emerging clinical and research evidence, was reported directly to the health minister and his department (Mindel and Kippax 2013).

The two committees did not act in harmony. Early on, the AIDS Task Force sought to use its medical authority to dominate the agenda, suggesting government establish compulsory testing and notification, enact stronger legislative controls in relation to homosexuality, prostitution and injecting drug use and close gay entertainment venues 
(Drielsma 1997). Blewett sought advice from NACAIDS, which argued that compulsory testing would drive people away and instead proposed the establishment of voluntary testing with counselling, peer-based support and nondiscriminatory care for people with AIDS (Drielsma 1997; Hulse 1997).

In November 1986, a third committee was established to manage the political response and ensure AIDS was not used as a political football (Blewett 1988). The Parliamentary Liaison Group, a nonpartisan committee of concerned federal Members of Parliament (MPs), was established to keep MPs abreast of the epidemic and the achievements of community-based education and prevention campaigns (Sendziuk 2003). Dr Peter Baume, opposition spokesman for health, played a critical role supporting Blewett through the management of divisive views within his own political party. Through the Parliamentary Liaison Group, the government was able to present a united political front on AIDS, which in turn enhanced the legitimacy of the response (Blewett 1988).

As the federal government confirmed its skill as consultant and negotiator, it also demonstrated clear leadership for the states and territories, which had initially considered AIDS too challenging and 'politically unattractive' (Misztal 1993: 125). Yet despite their general support, each jurisdiction had its own distinct legislative challenges - for example, disease monitoring, testing and data collection and service delivery procedures - to navigate (Misztal 1993). To implement the federal government's programs, the states and territories needed to engage with legislative frameworks to ensure the policy's overarching philosophical position of harm minimisation could be enacted (Madden and Wodak 2014). Not all state and territory governments embraced the principles of harm minimisation, community empowerment or the explicit education materials developed by the community. Queensland's conservative government, led by premier Joh Bjelke-Petersen, maintained homosexuality as a criminal act and refused to work with the local AIDS council or endorse its prevention efforts (Sendziuk 2003; Bowtell 2007).

Through concerted action, Blewett negotiated support at the 1985 Australian health ministers conference for the first National Health Strategy for the Control of AIDS-a precursor to the 1989 strategy (Department of Health 1986; Sendziuk 2003). As the federal government worked with the community to roll out its comprehensive and innovative package of prevention strategies_-including the infamous 'Grim Reaper' 
advertising campaign in 1987-it worked with the states and territories to establish matched funding to support this effort. In establishing funding agreements, the Commonwealth stipulated that at least half the funds were to be spent on peer-led education and community programs, and one-quarter of the prevention budget was to be administered by local AIDS councils (Hulse 1997; Sendziuk 2003; Mindel and Kippax 2013). Queensland again opposed this, but not to be blindsided, Blewett set about identifying novel ways to transfer funds to support education in that state, including using the Sisters of Mercy as 'holy money launderers' (Blewett 1997: 177).

Overall, through the establishment of the three central advisory committees, along with intensive engagement with the states and territories, the government built national consensus on HIV/AIDS in a participatory, collaborative manner (Ballard 1989).

\section{Enabling governance}

Acknowledging the feasibility and effectiveness of the community-led response, government became an enabler of community action, actively supporting and funding campaigns (Ballard 1989; Misztal 1991; Plummer and Irwin 2006; Power 2011; Mindel and Kippax 2013). Kippax and Race (2003: 2) argued that 'prevention was all that there was and whatever the misgivings and lack of faith, as well as moral and ideological posturing, there was a sense of urgency', which empowered government to pursue community activism. Describing the adoption of contextual, innovative and courageous strategies, Blewett (1996: 343) acknowledged this 'heroic period' as a time when 'we were explorers in an unknown land with monsters lurking in every covert. It had all the exhilaration and the danger of making policy where there was none' (Blewett 1997: 178).

During this 'heroic period', the potential for community outrage at the production of explicit preventive education material was ever present, but this was greatly reduced by distribution and dissemination through locations where only affected communities would see them (such as the gay press, sex-on-premise venues and social venues) (Hulse 1997; Willett 2014). Some adverse media attention did emerge, but governments (state and federal) continued to support and fund these materials, particularly in light of growing evidence of their effectiveness in raising awareness of HIV and increasing rates of safe sex (Mindel and Kippax 2013). 
Needle exchange programs were another example of an innovative, community-led harm-minimisation strategy that, coupled with the expansion of methadone maintenance treatment, became central to Australia's success in containing the spread of HIV, particularly through the community of injecting drug users (Madden and Wodak 2014). In 1985, following revelations that prime minister Bob Hawke's daughter was an injecting drug user, the federal government held a special premiers' conference, at which harm minimisation was officially adopted as part of the national drug policy-although how it was to be implemented in practice was not immediately apparent (Madden and Wodak 2014). The first needle exchange was established in 1986 in Sydney. This pilot was an illegal act of civil disobedience by local drug and alcohol workers, but the police did not prosecute and the NSW Government quickly responded by amending legislation and establishing a legal exchange program (Wodak and Lurie 1997; Madden and Wodak 2014). At the time, needle exchange was conceived as a 'plausible idea' rather than an intervention based on demonstrated effectiveness, but subsequent evaluation and research have demonstrated its effectiveness (Wodak and Lurie 1997). By 1993, all states had needle exchange programs (Wodak and Lurie 1997).

Another key intervention that saw the government lead the way in preventing the spread of HIV was in relation to protecting the blood supply (Plummer and Irwin 2005). Universal screening of the blood supply, adopted in April 1985, is attributed with reducing the transmission of HIV via medical procedures, from about 14 per cent in 1985 to less than 1 per cent in 1991-92 (Misztal 1991; Plummer and Irwin 2005; Mindel and Kippax 2013).

Overall, the first era of HIV/AIDS policy in Australia was characterised by strong leadership, effective partnerships, bipartisan political support and the active engagement of affected communities in the design, development and delivery of a multilevel strategy. In essence, this 'social public health' approach moved beyond traditional models of public health to recognise 'the collective nature of epidemics and work with affected communities and social networks to transform social relations' (Mindel and Kippax 2013: 350). The adoption by government of a social public health approach was groundbreaking for the time. Brown and colleagues (2014: 40) argue it demonstrates 
that an adaptive and politically active response working across multiple social, political, economic, behavioural and health-service levels, operating within supportive environments, are [sic] the most likely to reduce the transmission and impact of HIV.

Finally, as our narrative of the first era of policy draws to a close, we must acknowledge the affirmative evaluation of the first strategy and the sharp and continued decline in new HIV diagnoses following their peak in 1987 (Plummer and Irwin 2006). These outcomes provided government with confidence to continue to draw on the foundational principles of social public health in subsequent strategies, including the second national strategy, released in 1993 (Commonwealth of Australia 1993; Mindel and Kippax 2013). In essence, the foundations for policy success were laid early, but as we move to the next era, and the second act of our film, we see new challenges begin to emerge.

\section{6-2009: 'New hope, disinvestment and political neglect'}

The third national strategy was released in 1996 at the start of a new era of HIV in Australia - a period Brown et al. (2014: 37) label a time of 'new hope, disinvestment and political neglect'. Many changes were taking place at social, biomedical, political and epidemiological levels. Medical advances and the arrival of highly active antiretroviral therapy (HAART) in 1996 heralded 'new hope'; HIV could now be seen as a long-term, manageable chronic condition rather than an incurable disease (Newman et al. 2010).

In the same year, Australia elected a new conservative Commonwealth Government, led by John Howard. Howard's self-described 'socially conservative' government stood in stark contrast to the Hawke/Keating Labor governments. Yet despite early concerns that the government's 'tough on drugs' response would impact on HIV policy, it maintained a bipartisan approach and health minister Michael Wooldridge quietly continued to support and fund HIV-targeted harm-minimisation strategies, including needle and syringe programs (Madden and Wodak 2014). 
The third national strategy maintained the principles and goals of previous strategies, but was extended to include sexual health, hepatitis $\mathrm{C}$ and other communicable diseases (Department of Health and Family Services 1996; Mindel and Kippax 2013). This broadened policy framework led to the 'mainstreaming' of HIV funding, services and administrative processes within communicable disease structures (AFAO 2012). This was the first of many changes during this era that saw HIV policy shift from an innovative community-engaged space to 'a more "traditional" and "institutionalised" response' (Brown et al. 2014: 37). Advisory structures returned to the remit of elite experts (that is, doctors and bureaucrats), moving away from independent advice provided by affected communities (Bowtell 2007).

During this period, funding arrangements began to shift, in line with the neoliberalist agenda that was gaining momentum nationally and globally. The National Public Health Partnership established between the Commonwealth and states and territories developed outcome-based funding agreements, resulting in changes to service agreements and funding arrangements for community-based organisations (Bernard et al. 2008). In Victoria, this resulted in a 50 per cent decrease in funding for HIV programs as the conservative Victorian Government ceased the matched funding arrangement that had been in place for HIV prevention and services, and compulsory tendering was introduced (Bernard et al. 2008; Griew 2008). The result was a fracturing of partnerships and a significant loss of trust between the government and the community (Bernard et al. 2008).

On the eve of the fourth national strategy (1999-2004), there was a decreasing sense of urgency and an increasing level of political complacency in relation to HIV. For some, HIV had been controlled and significant investment was no longer needed (Moodie et al. 2003; Altman 2006). During this period, Tony Abbott assumed the role of federal health minister, resulting in further reductions in investment in programs that conflicted 'with the minister's support for "traditional values"' (Altman 2006: 52). Paradoxically, as funding began to decline, government interference increased, particularly in relation to the censorship of prevention materials (Altman 2006). 
The loss of momentum that occurred during this era was also seen in some sections of the gay community, as media coverage, public support and awareness and community engagement began to decline (Whittaker 2011). However, after a period of relative stability, new HIV diagnoses began to rise between 1999 and 2006, particularly among gay men in Victoria and Queensland (Mindel and Kippax 2013). As a consequence, the need for renewed effort received some attention in the fifth national strategy (2005-08), which reemphasised prevention, education, early diagnosis and treatment (Mindel and Kippax 2013).

In 2007, a bolder analysis of the increasing incidence in HIV was driven by New South Wales, which established a national taskforce of leading social and epidemiological researchers, clinicians, state-based bureaucrats, HIV community members and an observer from the Commonwealth Government (Mindel and Kippax 2013). The taskforce debated explanations for the increased incidence, particularly in relation to changing sexual practices; however, New South Wales was able to demonstrate how-through ongoing commitment to partnerships with the community and continued investment in community-led education and prevention programs - it had managed to contain incidence rates (O’Donnell et al. 2010). In contrast, Victoria's decreased investment and fracturing relationships appeared to be associated with an increasing incidence of HIV diagnoses (Bernard et al. 2008; Fairley et al. 2008).

As we draw an end to the second act, we illustrate that, despite the establishment of strong foundations in the first era, temporal and contextual elements in the second era challenged the policy success. Biomedical advancements in HIV were groundbreaking, but these fed into neoliberal discourses of individual responsibility for health. The role of government as consultant, negotiator and enabler changed to a new role as controller of (shifting) funding arrangements and service agreements. Increasing tensions emerged between policy partners and fatigue rose in the gay community-battle weary after years on the front line of the response. Incidence rates started to rise, particularly in states that had disinvested. The focus on social public health began to wane and biomedicalisation took hold. However, although tensions emerged, the core underlying values base of human rights and partnerships continued to drive a multifaceted, collaborative national policy response. 


\section{0 - present: Biomedicine and a time of targets}

Since the introduction of HAART in 1996, biomedical advances in HIV prevention and treatment have gained considerable pace. In the third policy era, biomedicine has assumed centre-stage and now dominates the HIV landscape. During this time, the Sixth National HIV Strategy 2010-2013 was implemented and the Seventh National HIV Strategy 2014-2017 was released (an eighth strategy is in development). Drawing on the 2011 United Nations Political Declaration on HIV and AIDs (UNAIDS 2011), the seventh strategy was the first national strategy to set key targets guiding Australia 'towards the elimination of HIV transmission by 2020' (Department of Health 2014: 1; O’Donnell and Perche 2016).

During this era, clinical trials have played a central role in the increasing predominance of biomedicine. In particular, the results of the $2011 \mathrm{HIV}$ Prevention Trials Network 052 trial were instrumental in demonstrating the efficacy of antiretroviral treatment (ART) in reducing HIV transmission among serodiscordant couples, when the HIV-positive partner had an undetectable viral load (Cohen et al. 2011). From this, the Joint United Nations Programme on HIV/AIDS (UNAIDS) moved to establish treatment as prevention as a core policy agenda. Treatment as prevention is founded on the principles that regular HIV testing, early initiation of treatment and achievement of an undetectable viral load are central to achieving reductions in the transmission of HIV and the elimination of the disease (Montaner et al. 2014; UNAIDS 2014a, 2014b).

To promote regular testing, Australia has adopted key testing technologies, including rapid point-of-care testing for HIV—a quick and reliable alternative to conventional testing that provides results within 30 minutes, without the need for clinical supervision or laboratory analysis (Arora et al. 2013). Australia approved point-of-care testing in 2011 as part of its National HIV Testing Policy and has supported its rollout across nonclinical and community settings including sex-onpremise venues (Mutch et al. 2017).

PrEP, a third key element of biomedicine's HIV prevention armoury, has been adopted in Australia. The $2010 \mathrm{iPrEx}$ trial demonstrated the efficacy of Truvada (an ART) for PrEP to prevent the acquisition of HIV (Grant et al. 2014; Brown et al. 2015). In 2018, the Australian Pharmaceutical Benefits Advisory Committee approved its inclusion on the PBS. 
This third era of 'targets and biomedicine' is a time of hope and anticipation as we potentially near the 'end of AIDS' and set targets to end new cases of HIV by 2020 (Holt 2017). We now have the biotechnology to prevent the transmission of HIV with treatment as prevention and PrEP, but as a consequence we see an increasing dominance and influence of biomedicalisation on policy formation (Aggleton and Kippax 2014). Policy attention has shifted to the 'front end' of the response, diverted from the social and legislative factors that were the cornerstone of our early response and fundamental to a social public health approach. Tensions have emerged between partnerships-particularly affected communities and policymakers-over the focus on the biomedical at the expense of the social, particularly the psychosocial needs of PLHIV (Cameron and Godwin 2014). Policy and associated funding are increasingly attached to the number of people tested on treatment and with undetectable viral loads. But through these changes the core values and program base of the Australian national HIV policy continues, although tensions remain between partners due to funding uncertainty and tender processes that pit partners against each other (O’Keefe and Forbes 2015).

Despite these challenges, target setting has brought partners together with renewed energy as HIV becomes an item on the policy agenda for politicians keen to 'end HIV' on their watch. Policymakers, clinicians, researchers and communities are again working collaboratively to drive programmatic and policy development and maintain the core values of Australia’s HIV response (AFAO 2012; Muchamore 2015).

\section{Analysis and conclusions}

Australia's policy response to HIV/AIDS provides key lessons for understanding policy success. First, context matters. The early phases of the epidemic occurred within a unique social and political context-a 'perfect storm' in which new ways of doing public health policy based on human rights and community partnerships was emerging. Advocacy, the mobilisation of affected communities and a government unafraid to make bold policy decisions and take on the role of consultant, negotiator and enabler were central to the collective development of a pragmatic, multifaceted policy response. Core values, programmatic design, multifaceted policy instruments and bipartisan political support central to the first era have carried through three subsequent eras and 
seven national strategies. However, while there is a tendency to bask in this success, critical analysis using a temporal lens demonstrates that some key features have waned over time as the context of HIV has changed, particularly in relation to biomedical advancements, neoliberal policy agendas and the corresponding impact on relationships between governments and community organisations.

What were key foundations of policy success? Australia's response to HIV/AIDS was bipartisan, collaborative and well funded (Holt 2017). Early success is attributed to immediate action by affected communities (particularly gay men, people who inject drugs and sex workers and Aboriginal and Torres Strait Islander peoples), who drove education and prevention messages, resulting in changes in community practices around safe sex and safe injecting (Plummer and Irwin 2006; Aggleton and Kippax 2014; Holt 2017). Success at the policy level is embedded in the government's role as an enabler, harnessing community mobilisation (Brown et al. 2014). Collaborative partnerships between affected communities, community organisations, clinicians, researchers and governments were fundamental.

A 'social public health approach' was foundational in directing the development and delivery of policy (Aggleton and Kippax 2014). This broader social focus facilitated and enabled the social and legal environments for priority populations and sustained government funding of multipronged interventions across national, state, community and health services (Brown et al. 2014). Multiple forms of evidence drawn from the community and research informed 'an effective yet malleable response' (Aggleton and Kippax 2014: 189; Brown et al. 2014).

Sustained leadership was a key feature. The role of Blewett and his pragmatic, bipartisan approach-which actively engaged the community and allowed the states and territories to drive and develop interventions and strategies particular to their localised epidemics-was central to Australia's success (Brown et al. 2014).

Advocacy and investment were also critical to policy success (Brown et al. 2014). Yet, despite international recognition of Australia's effort, fatigue, complacency, political drift and some fractured partnerships have impeded recent progress and sustained low incidence rates, and the success of new biomedical treatment and prevention has also contributed to HIV slipping from the centre of the policy agenda (Moodie et al. 2003; 
Cameron and Godwin 2014; O'Donnell and Perche 2016). This slip began in the 1990s with the 'mainstreaming' of HIV funding and services (Bowtell 2005). Complacency and 'HIV fatigue' occurred in the policy arena, in health departments and the broader community as the 'threat' subsided in Australia (Moodie et al. 2003). However, differences across the states and territories in the types of prevention strategies used and financial investments made are inextricably connected to the effectiveness of the ongoing response to HIV (Bernard et al. 2008). State and territory governments that reduced investment and capacity, particularly in the second era, were 'less successful in responding to the complexities of changing epidemics, social practices and cultural engagement' (Brown et al. 2014: 37).

\section{Future challenges}

Australia is at a crossroads in HIV; it is a time of both 'unprecedented opportunity and ongoing challenge' (Department of Health 2014: iii). The biomedicalisation of prevention and treatment has given us the knowledge to substantially reduce new HIV infections and perhaps herald the 'end of AIDS', but after nearly four decades of the epidemic, along with restrictions on national budgets and health spending, there is some sense of weariness and complacency (Whittaker 2014). Continuing policy success requires regeneration of partnerships, with the agility to respond to changing epidemiological and medical developments. Organisations representing PLHIV emphasise future challenges of better recognising and meeting the needs of marginalised communities not currently benefiting equally from Australia's HIV response (Kirby Institute 2018). These challenges include the meaningful involvement of and expert contributions from PLHIV (NAPWHA 2017); we cannot risk leaving behind those communities most affected.

Future challenges also include an ageing population of PLHIV with increasing comorbidities, the increasing diversity of affected communities, rising rates of HIV in particular communities, including Aboriginal and Torres Strait Island peoples, and a complexity of interactions between biomedical, social, behavioural and structural responses (Aggleton et al. 2011; Brown et al. 2014; Holt 2017; Ward et al. 2018). These are complex and crosscutting issues that need careful policy development and analysis. 
From the beginning of the epidemic in Australia, community groups highlighted the need to address structural barriers and enablers to reduce the epidemic. Criminal sanctions relating to HIV transmission, the lack of drug law reform and the continued criminalisation of sex work still hamper evidence-based health promotion (ACT Human Rights and Discrimination Commission 2013). A human rights agenda requires decriminalisation of drug use to provide an enabling environment for health promotion and decriminalisation of peer distribution of syringes (Cameron and Godwin 2014). Decriminalisation of adult sex work is needed to ensure continuing safety and effective HIV prevention in the sex industry (Bates and Berg 2014). Law reform to enhance enabling environments requires political leadership and commitment beyond the health sector, with the support of champions and advocacy from multiple sectors. Long-established structures and agencies in the health and community sectors need to innovate and evolve (Muchamore 2015).

The values base of human rights, partnership and collaboration has underpinned the HIV policy response with great success, but we still have a way to go. Social public health alongside biomedical advances must drive policy success into the fifth decade of the national HIV/AIDS policy if we are to see real policy success and the elimination of new cases of HIV and ensure no one is left behind (Kippax et al. 2013). Having now looked through our historical film of Australia's response to HIV/AIDS and considered the intersections between the social, political and generational contexts that drove policy and action during those early years, we leave our cinema goers with an important point of reflection: would such a successful policy response be possible today?

\section{References}

ACT Human Rights and Discrimination Commission 2013. Legal issues in Australian public health: A series of 7 papers on the impacts of discrimination and criminalisation on public health approaches to blood borne viruses and sexually transmissible infections. Prepared for the Commonwealth Ministerial Advisory Committee on Blood-Borne Viruses and STIs. Canberra.

Aggleton, P. and Kippax, S. 2014. 'Australia's HIV prevention response: Introduction to the special issue.' AIDS Education and Prevention 26: 187-90. doi.org/10.1521/aeap.2014.26.3.187. 
Aggleton, P., Yankah, E. and Crewe, M. 2011. 'Education and HIV/AIDS: 30 years on.' AIDS Education and Prevention 23(6): 495-507. doi.org/10.1521/ aeap.2011.23.6.495.

Altman, D. 1994. Power and Community: Organizational and cultural responses to AIDS. London: Taylor \& Francis.

Altman, D. 2006. 'The margins of our attention: 25 years of HIV and AIDS.' The Monthly 58(Dec-Jan): 52-6.

Applied Economics 2003. Returns on Investment in Public Health: An epidemiological and economic analysis prepared for the Department of Health and Ageing. Canberra: Department of Health and Ageing.

Arora, D. R., Maheshwari, M. and Arora, B. 2013. 'Rapid point-of-care testing for detection of HIV and clinical monitoring.' ISRN AIDS 2013. doi.org/ $10.1155 / 2013 / 287269$.

Australian Federation of AIDS Organisations (AFAO) 2012. Implementing the United Nations Political Declaration on HIVIAIDS in Australia's Domestic HIV Response: Turning political will into action. Sydney: AFAO.

Ballard, J. 1989. 'The politics of AIDS.' In H. Gardner (ed.), The Politics of Health: The Australian experience. Melbourne: Churchill Livingstone.

Bates, J. and Berg, R. 2014. 'Sex workers as safe sex advocates: Sex workers protect both themselves and the wider community from HIV.' AIDS Education and Prevention 26: 191-201. doi.org/10.1521/aeap.2014.26.3.191.

Bernard, D., Kippax, S. and Baxter, D. 2008. 'Effective partnership and adequate investment underpin a successful response: Key factors in dealing with HIV increases.' Sexual Health 5: 193-201. doi.org/10.1071/SH07078.

Blewett, N. 1988. 'Political dimensions of AIDS.' AIDS 2: S235-S238. doi.org/ 10.1097/00002030-198800001-00036.

Blewett, N. 1996. 'Valuing the past ... investing in the future.' Australian and New Zealand Journal of Public Health 20(4): 343-5. doi.org/10.1111/j.1467842X.1996.tb01042.x.

Blewett, N. 1997. 'An inside view: Comments on Hulse's "Australia's public health response to HIV and HCV: A role for 'affected' communities".' Drug and Alcohol Review 16: 177-8. doi.org/10.1080/09595239700186471.

Bowtell, W. 1997. 'A successful model of public health management: Comments on Hulse's "Australia's public health response to HIV and HCV: A role for 'affected' communities".' Drug and Alcohol Review 16: 180-1. 
Bowtell, W. 2005. Australia's Response to HIVIAIDS 1982-2005. Sydney: Lowy Institute for International Policy.

Bowtell, W. 2007. 'Applying the paradox of prevention: Eradicate HIV.' Griffith Review 17(Spring): 11-42.

Brandt, A. 1986. 'AIDS: from social history to social policy.' Law, Medicine \& Health Care: A publication of the American Society of Law \& Medicine 14: 231. doi.org/10.1111/j.1748-720X.1986.tb00990.x.

Brown, G., O’Donnell, D., Crooks, L. and Lake, R. 2014. 'Mobilisation, politics, investment and constant adaptation: Lessons from the Australian health-promotion response to HIV.' Health Promotion Journal of Australia 25: 35-41. doi.org/10.1071/HE13078.

Brown, G., Reeders, D., Dowsett, G. W., Ellard, J., Carman, M., Hendry, N. and Wallace, J. 2015. 'Investigating combination HIV prevention: Isolated interventions or complex system.' Journal of the International AIDS Society 18(1). doi.org/10.7448/IAS.18.1.20499.

Cameron, S. and Godwin, J. 2014. 'Barriers to legal and human rights in Australia in the era of HIV treatment as prevention.' AIDS Education and Prevention 26: 202-13. doi.org/10.1521/aeap.2014.26.3.202.

Centers for Disease Control and Prevention (CDC) 2006. Evolution of HIV/ AIDS prevention programs: United States, 1981-2006.' MMWR: Morbidity and Mortality Weekly Report 55(21): 597.

Centers for Disease Control and Prevention (CDC) 2018. Estimated HIV incidence and prevalence in the United States, 2010-2015. HIV Surveillance Supplemental Report 23 (No. 1). Atlanta, GA: CDC.

Cohen, M. S., Chen, Y. Q., McCauley, M., Gamble, T., Hosseinipour, M. C., Kumarasamy, N., Hakim, J. G., Kumwenda, J., Grinsztejn, B., Pilotto, J. H. S., Godbole, S. V., Mehendale, S., Chariyalertsak, S., Santos, B. R., Mayer, K. H., Hoffman, I. F., Eshleman, S. H., Piwowar-Manning, E., Wang, L., Makhema, J., Mills, L. A., De Bruyn, G., Sanne, I., Eron, J., Gallant, J., Havlir, D., Swindells, S., Ribaudo, H., Elharrar, V., Burns, D., Taha, T. E., NielsenSaines, K., Celentano, D., Essex, M. and Fleming, T. R. 2011. 'Prevention of HIV-1 infection with early antiretroviral therapy.' The New England Journal of Medicine 365: 493-505. doi.org/10.1056/NEJMoa1105243.

Commonwealth of Australia 1989. National HIVIAIDS strategy: A policy information paper. Canberra: AGPS.

Commonwealth of Australia 1993. National HIVIAIDS Strategy 1993-94 to 1995-96: Valuing the past ... investing in the future. Canberra: AGPS. 
Department of Health 1986. Australia's Response to AIDS. Canberra: Commonwealth of Australia.

Department of Health 2014. Seventh National HIV Strategy 2014-2017. Canberra: Commonwealth of Australia.

Department of Health and Family Services 1996. Partnerships in Practice: National HIVIAIDS strategy 1996-97 to 1998-99. Canberra: AGPS.

Donovan, B., Harcourt, C., Egger, S., Watchirs Smith, L., Schneider, K., Kaldor, J., Chen, M., Fairley, C. and Tabrizi, S. 2012. The sex industry in New South Wales: A report to the NSW Ministry of Health. Sydney: Kirby Institute.

Drielsma, P. 1997. 'AIDS policy and public health models: An Australian analysis.' Australian Journal of Social Issues 32: 87-99. doi.org/10.1002/ j.1839-4655.1997.tb01293.x.

Fairley, C. K., Grulich, A. E., Imrie, J. C. and Pitts, M. 2008. 'Investment in HIV prevention works: A natural experiment.' Sexual Health 5: 207-10. doi.org/10.1071/SH08017.

Feachem, R. 1995. Valuing the Past ... Investing in the Future: Evaluation of the National HIVIAIDS Strategy 1993-94 to 1995-96. Canberra: AGPS.

Grant, R. M., Anderson, P. L., McMahan, V., Liu, A., Amico, K. R., Mehrotra, M. and Buchbinder, S. 2014. 'Uptake of pre-exposure prophylaxis, sexual practices, and HIV incidence in men and transgender women who have sex with men: A cohort study.' The Lancet Infectious Diseases 14: 820-9. doi.org/ 10.1016/S1473-3099(14)70847-3.

Griew, R. 2008. 'Policy and strategic implications of Australia's divergent HIV epidemic among gay men.' Sexual Health 2: 203-5. doi.org/10.1.1.553.977.

Gupta, G. R., Parkhurst, J. O., Ogden, J. A., Aggleton, P. and Mahal, A. 2008. 'Structural approaches to HIV prevention.' The Lancet 372: 764-75. doi.org/ 10.1016/S0140-6736(08)60887-9.

Holt, M. 2017. 'Progress and challenges in ending HIV and AIDS in Australia.' AIDS and Behavior 21(2): 331-4. doi.org/10.1007/s10461-016-1642-0.

Hulse, G. K. 1997. 'Australia's public health response to HIV and HCV: A role for “affected” communities.' Drug and Alcohol Review 16(2): 171-6. doi.org/ $10.1080 / 09595239700186461$.

Joint United Nations Programme on HIV/AIDS (UNAIDS) 2011. Political Declaration on HIV and AIDS: Intensifying our efforts to eliminate HIV and AIDS. Geneva: UNAIDS. 
Joint United Nations Programme on HIV/AIDS (UNAIDS) 2014a. 90-90-90: An ambitious treatment target to help end the AIDS epidemic. Geneva: UNAIDS.

Joint United Nations Programme on HIV/AIDS (UNAIDS) 2014b. Fast-Track: Ending the AIDS epidemic by 2030. Geneva: UNAIDS.

Kippax, S. and Race, K. 2003. 'Sustaining safe practice: Twenty years on.' Social Science and Medicine 57: 1-12. doi.org/10.1016/S0277-9536(02)00303-9.

Kippax, S., Stephenson, N., Parker, R. G. and Aggleton, P. 2013. 'Between individual agency and structure in HIV prevention: Understanding the middle ground of social practice.' American Journal of Public Health 103: 1367. doi.org/10.2105/AJPH.2013.301301.

Kirby Institute 2018. HIV in Australia: Annual surveillance short report 2018. Sydney: Kirby Institute.

Kirwan, P., Chau, C., Brown, A., Gill, O., Delpech, V. and Contributors 2016. HIV in the UK: 2016 Report. London: Public Health England.

Kwon, A. J., Anderson, C. J., Kerr, J. C., Thein, M. H.-H., Zhang, G. L., Iversen, P. J., Dore, P. G., Kaldor, P. J., Law, P. M., Maher, P. L. and Wilson, P. D. 2012. 'Estimating the cost-effectiveness of needle-syringe programs in Australia.' AIDS 26: 2201-10. doi.org/10.1097/QAD.0b013e3283578b5d.

Madden, A. and Wodak, A. 2014. 'Australia's response to HIV among people who inject drugs.' AIDS Education and Prevention 26: 234-44. doi.org/10.1521/ aeap.2014.26.3.234.

Mindel, A. and Kippax, S. 2013. 'A national strategic approach to improving the health of gay and bisexual men: Experience in Australia.' In S. Aral, K. Fenton and J. Lipshutz (eds), The New Public Health and STD/HIV Prevention: Personal, public and health system approaches. New York: Springer. doi.org/10.1007/978-1-4614-4526-5_17.

Misztal, B. A. 1991. 'HIV/AIDS policies in Australia: Bureaucracy and collective action.' International Journal of Sociology and Social Policy 11(4): 62-82. doi.org/10.1108/eb013137.

Misztal, B. 1993. 'Management of HIV/AIDS in the Australian federal system.' Social Policy \& Administration 27(2): 124-40. doi.org/10.1111/j.1467-9515. 1993.tb00396.x. 
Montaner, J., Lima, V., Harrigan, P., Lourenço, L., Yip, B., Nosyk, B., Wood, E., Kerr, T., Shannon, K., Moore, D. and Hogg, R. S. 2014. 'Expansion of HAART coverage is associated with sustained decreases in HIV/AIDS morbidity, mortality and HIV transmission: The "HIV treatment as prevention" experience in a Canadian setting.' PLOS One 9(2): e87872. doi.org/10.1371/ journal.pone. 0087872 .

Moodie, R., Edwards, A. and Payne, M. 2003. 'Review of the national HIV/ AIDS strategy 1999-2000 to 2003-04: Getting back on track ... revitalising Australia's response to HIV/AIDS.' In A. Wilson, N. Partridge and L. Calzavara (eds), 2002 Reviews of the National HIVIAIDS and Hepatitis C Strategies and Strategic Research. Canberra: Commonwealth of Australia.

Muchamore, I. 2015. 'Communities, policies and the enabling environment.' HIV Australia 13: 5-6.

Mutch, A., Lui, C. W., Dean, J., Mao, L., Lemoire, J., Debattista, J., Howard, C., Whittaker, A. and Fitzgerald, L. 2017. 'Increasing HIV testing among hard-to-reach groups: Examination of RAPID, a community-based testing service in Queensland, Australia.' BMC Health Services Research 17. doi.org/ 10.1186/s12913-017-2249-5.

National Association of People with HIV Australia (NAPWHA) 2017. Annual Report 2016-2017. Sydney: NAPWHA.

Newman, C., Mao, L., Canavan, P., Kidd, M., Saltman, D. and Kippax, S. 2010. 'HIV generations? Generational discourse in interviews with Australian general practitioners and their HIV positive gay male patients.' Social Science and Medicine 70: 1721-7. doi.org/10.1016/j.socscimed.2010.02.006.

Nous Group 2015. 'The Nous Project: Exploring the value of the communitybased organisations in Australia's HIV response.' HIV Australia 14(2): 12-14.

O'Donnell, D. and Perche, D. 2016. 'Resetting the agenda: The makings of “a new era”.' Sexual Health 13: 328-34. doi.org/10.1071/SH16010.

O’Donnell, D., Grulich, A., Garsia, R., Parkhill, N. and Browne, K. 2010. 'HIV in NSW in 2010: Sustaining success in an evolving epidemic.' NSW Public Health Bulletin 21: 49-53. doi.org/10.1071/NB10022.

O'Keefe, F. and Forbes, L. 2015. 'Target-setting: Australia and the global context.' HIV Australia 13(1): 4.

Perrow, C. and Guillen, M. F. 1990. The AIDS Disaster: The failure of organizations in New York and the nation. New Haven, CT: Yale University Press. 


\section{SUCCESSFUL PUBLIC POLICY}

Plummer, D. and Irwin, L. 2006. 'Grassroots activities, national initiatives and HIV prevention: Clues to explain Australia's dramatic early success in controlling the HIV epidemic.' International Journal of STD \& AIDS 17(12): 787-93.

Power, J. 2011. Movement, Knowledge, Emotion: Gay activism and HIVIAIDS in Australia. Canberra: ANU E Press.

Robinson, S. and Wilson, E. 2012. 'Working together? Medical professionals, gay community organisations and the response to HIV/AIDS in Australia, 1983-1985.' Social History of Medicine 25(3): 701-18. doi.org/10.1093/shm/ hkr172.

Sendziuk, P. 2003. Learning to Trust: Australian responses to AIDS. Sydney: UNSW Press.

Ward, J., Costello-Czok, M., Willis, J., Saunders, M. and Shannon, C. 2014. 'So far, so good: Maintenance of prevention is required to stem HIV incidence in Aboriginal and Torres Strait Islander communities in Australia.' AIDS Education and Prevention 26: 267-79. doi.org/10.1521/aeap.2014.26.3.267.

Ward, J., McManus, H., McGregor, S., Hawke, K., Giele, C., Su, J. Y., McDonald, A., Guy, R., Donovan, B. and Kaldor, J. M. 2018. 'HIV incidence in Indigenous and non-Indigenous populations in Australia: A population-level observational study.' The Lancet HIV 5(9): e506-e514. doi.org/10.1016/ S2352-3018(18)30135-8.

Whittaker, A. M. 1992. 'Living with HIV: Resistance by positive people.' Medical Anthropology Quarterly 6:385-90. doi.org/10.1525/maq.1992.6.4.02a00050.

Whittaker, B. 2011. 'Australia should lead a global HIV prevention revolution.' HIV Australia 9: 7-8.

Whittaker, B. 2014. 'Transforming Australia's HIV prevention and treatment efforts to achieve an AIDS-free generation: The United Nations political declaration on HIV/AIDS and the Melbourne declaration "Action on HIV".' Sexual Health 11: 101-6. doi.org/10.1071/SH13056.

Willett, G. 2014. 'How we saved our lives: The gay community and the Australian response to AIDS.' HIV Australia 12(3): 4.

Wodak, A. and Lurie, P. 1997. 'A tale of two countries: Attempts to control HIV among injecting drug users in Australia and the United States.' Journal of Drug Issues 27: 117-34. doi.org/10.1177/002204269702700108. 
This text is taken from Successful Public Policy: Lessons from Australia and New Zealand, edited by Joannah Luetjens, Michael Mintrom and Paul 't Hart, published 2019 by ANU Press, The Australian National University, Canberra, Australia.

doi.org/10.22459/SPP.2019.02 